\title{
Isabella Christine McLennan
}

\section{by Rosemary Turpin}

This is a brief biography of Isabella Christine McLennan, who, in spite of the fact that she never attended McGill, was a most generous benefactor. She was born in 1870, the youngest of thirteen children of the highly successful industrialist, Hugh McLennan. Although she never married or chose a career, she managed her inheritances so well that she was able to will McGill University about one million dollars, enough to build the new McLennan Library, which was named after her at its inauguration in 1969.

She died in 1960, at the age of eighty-nine, after a fairly quiet life which focused largely on her family and philanthropic pursuits which included the McLennan Travelling Libraries, and McGill University, where she set up several scholarships. Others included the Montreal General Hospital, the Royal Victoria Hospital and the Royal Victoria College, all affiliated with McGill.

Il s'agit d'une brève biographie d'Isabella Christine McLennan qui, sans jamais avoir fait d'études à McGill, a su se montrer extrêmement généreuse envers l'Université. Née en 1870, Isabella est la plus jeune des treize enfants du riche industriel Hugh McLennan. Même si elle ne s'est jamais mariée et n'a embrassé aucune carrière, elle a su si bien gérer sa fortune qu'elle a pu léguer à l'Université McGill près d'un million de dollars, suffisamment pour construire la nouvelle bibliothèque McLennan dont l'inauguration remonte à 1969.

Isabelle Mclennan est décédée en 1960 à l'âge de quatre-vingt-neuf ans après une vie relativement sereine, principalement consacrée à sa famille et à ses oeuvres philanthropique comme les bibliothèques itinérantes McLennan et diverses bourses à l'Université McGill. Elle a également fait des dons à l'Hôpital général de Montréal, à l'Hôpital Royal Victoria et au Collège Royal Victoria qui sont tous affiliés à l'Université.

I sabella McLennan lived a long, full and busy life. She never had a professional career, which was not unusual for a woman of her class and time, but she never married, which was somewhat unusual. However, she was a member of a close and loving family, and was a busy socialite and a generous donor to many different charitable organizations and institutions.

Researching the early part of Isabella's life (18701904) was comparatively easy because McGill's Department of Rare Books and Special Collections has a wonderful document file on her family. Her brother, John Stewart McLennan, had recorded her birth and described other members of their family in his privately published book about his industrialist father, Hugh McLennan. ${ }^{1}$ Her other brother Hugh Stewart had copied small sections of letters she wrote as an adolescent into his Commonplace Book, ${ }^{2}$ which unfortunately was terminated when he died in 1892. Also, the McCord Museum had a number of very interesting photographs of her and her family on file.

The latter part of her life, (1905-1960) however, is sparsely documented. John's book provided a complete family chronology which extended thirty-four years beyond the death of his father. However, Isabella was a very shy person who apparently neither assumed any club offices nor had any desire to shine publicly. Only a very few personal letters have yet been found in the McGill Archives. She was almost certainly present at most family occasions, as well as many social events; she travelled to Europe for a social season once every year or so, and moved to the family's country home during most summers until 1924.

\section{ISABELLA MCLENNAN: TO AGE 18 (1870-1888)}

Isabella Christine McLennan was barely a postscript in her brother's biography about their father, Hugh McLennan. John Stewart McLennan wrote:

And to complete the family growth it may be noted here that Bartlett was born on 10th 


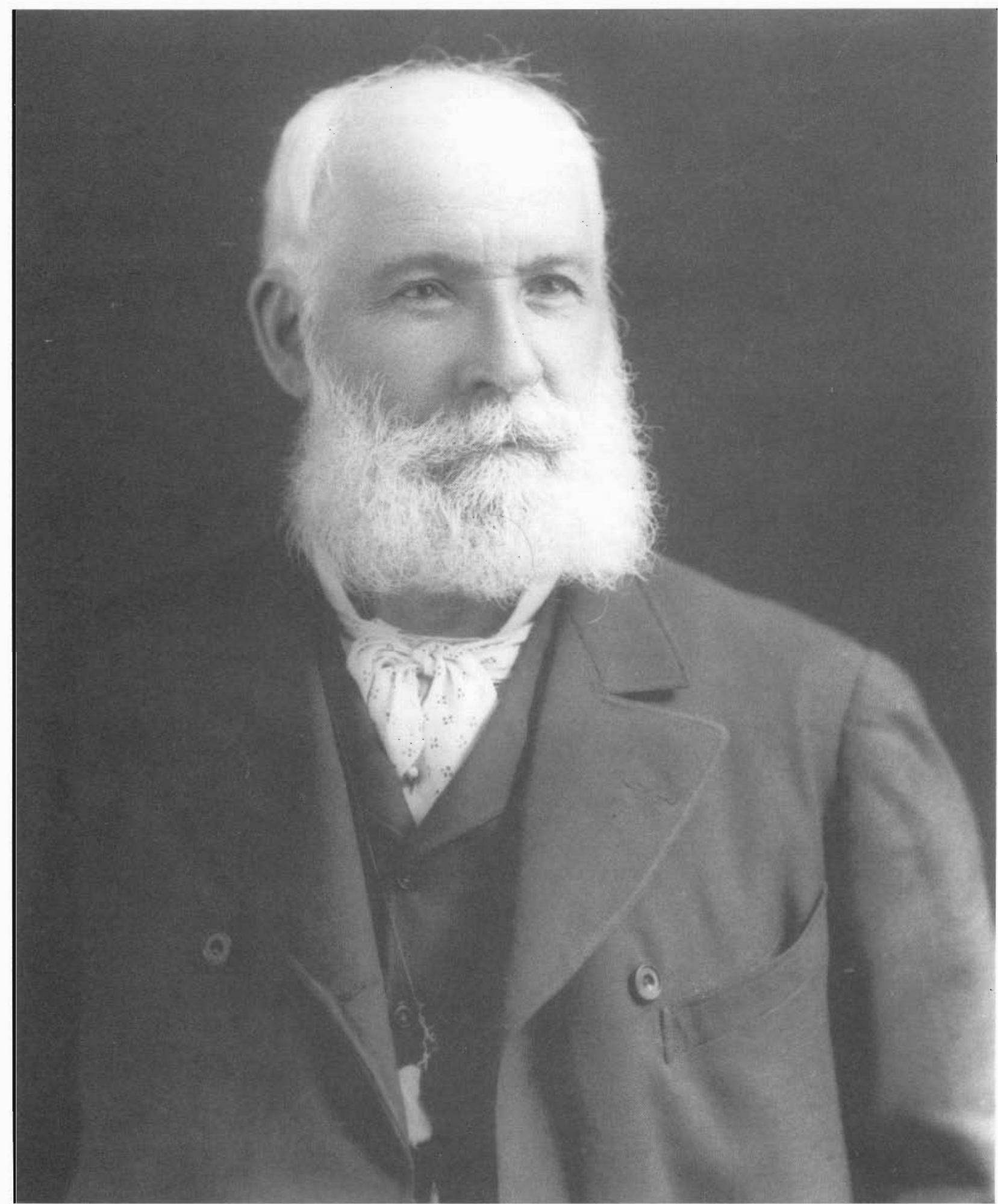

Figure 1. Hugh McLennan, 1890. (Notman Photographic Archives, McCord Museum of Canadian History) 


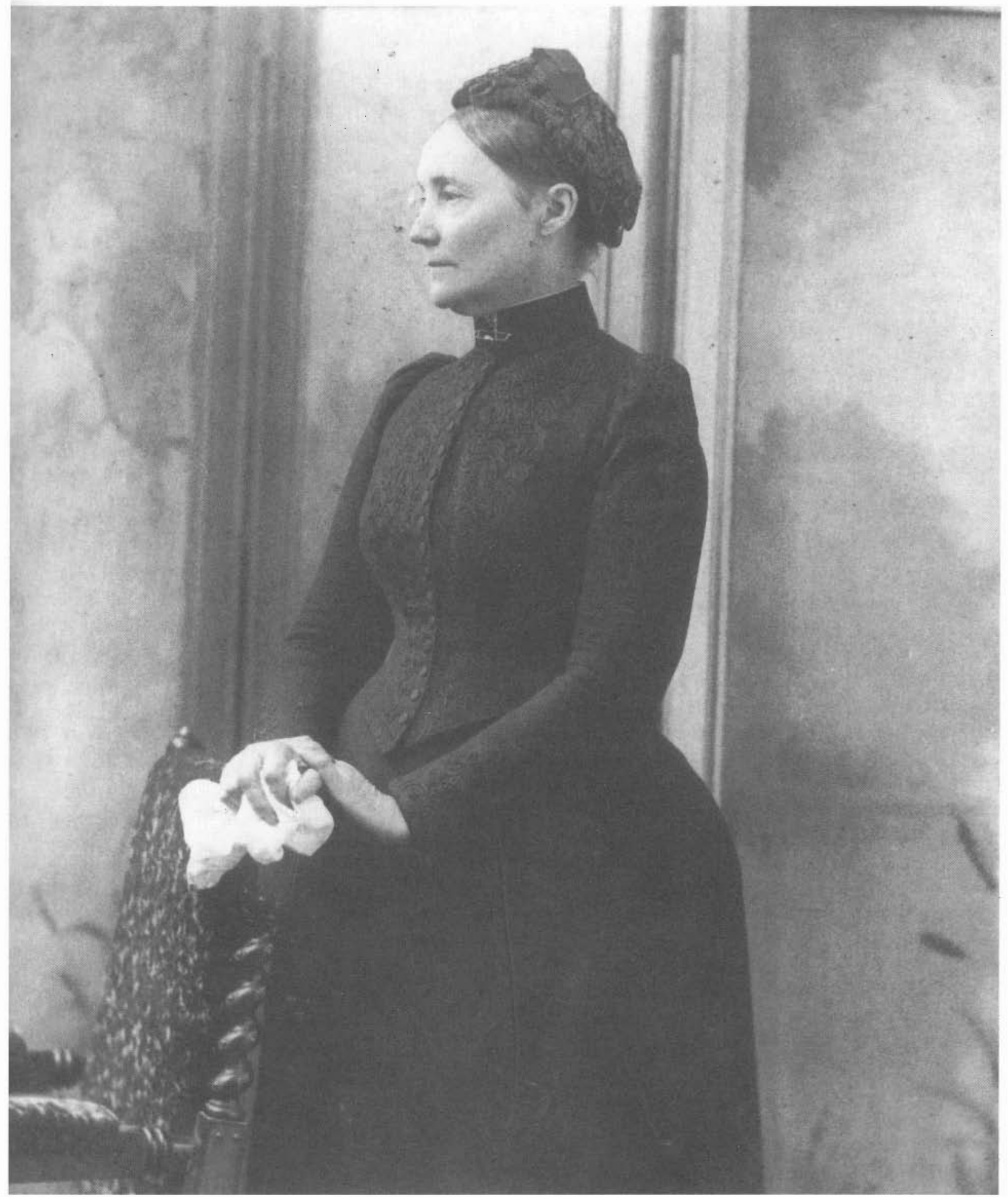

Figure 2. Isabella (née Stewart) McLennan, 1890. (Notman Photographic Archives, McCord Museum of Canadian History) 
November, 1868, and Belle on 30th November, $1870 .^{3}$

In a letter written when Belle was three days old, her father describes her fondly thus:

...the centre of interest in such cases being the baby - she is well and matured already to a degree of wakefulness more active than agreeable.- has a good appetite, and her personal appearance suggests that the babies of this year are above the average of good looks. ${ }^{4}$

Sometime over the next eighty-nine years, Isabella (Belle) became a woman of such substance that she was able to bequeath McGill University over a million dollars in 1960 , which was then enough to establish the new McLennan Library; yet very little was publicly known about either ber or her family.

Isabella was the thirteenth child and fourth daughter of Hugh McLennan and Isabella Stewart (Figs. 1 \& 2). Two of her older brothers and two older sisters had died in infancy before she was born. ${ }^{5}$

Her eldest brother, John Stewart McLennan, was 17 when Isabella was born. There would bave been anywhere up to nine children or young adults living in their Drummond Street home when Isabella was growing up ${ }^{6}$ (Fig. 3). In those days, children usually lived with their parents until they married.

They were a very close family, corresponding with one another, and visiting one another frequently. Isabella's ancestors were Scots on both sides. There are Stewarts, McLeods and McCanns on her mother's side and Mackenzies and Mackays on the McLennan side. John McLennan's book gives all the historical information he could find going back several generations.

Information about Isabella's early schooling is sparse or non-existent, except for the following possibility. Her sister Alice and her brothers Neil, Hugh and Alec, went to Mrs. Watson's School on McGill College Avenue. ${ }^{8}$ It is likely that Isabella went there too, if the family kept up the established tradition.
It appears that she learned at least some German, played the piano micely and learned the etiquette and social graces that a young lady of her class and period were required to know.

On July 13,1888, when she was $171 / 2$, she wrote to her cousin Alice (Charles Ronald Stewart's daughter) at The Lindens, Ottawa:

What did the storm for you? Ours was a most demoralized looking place. One of our fine (five?) evergreens was beheaded-and five or six of our trees destroyed. It was terrific and there has (sic) been high winds ever since till this evening without ... rain. Our garden is almost as bad as last year-the buds are drying up on the stalks and there was promise of a great show of flowers. ${ }^{9}$

On August 24, 1888, Isabella's mother wrote that

Belle is having a fine visit with Miss [Alma] Stuart. It has rained every day but she doesn't mind as she sits by a wood fire and Miss Stuart and she read German and moralize over men and things... ${ }^{10}$

(Alma Stuart married Isabella's brother Francis eight years later.)

In a letter Alma wrote in September 1888, she reveals that she had learned to know and appreciate Belle's many attractive qualities of mind and beart."

Alice wrote to her brother Hugh (Hugo) on September 28, 1888, saying:

I wish you could hear Belle play and she loves to be at the piano-won't we miss her. ${ }^{12}$

Isabella went to Meadowbrook, a finishing school in Boston for a year in 1888-89. Alma Stuart noted in a letter dated November 8,1888 , that Belle bad a year for study in Boston. ${ }^{13}$ This year included cultural education and probably training in household management and social graces. When she left for Boston, she would have been almost eighteen, and probably just ready to "come out" in society. 


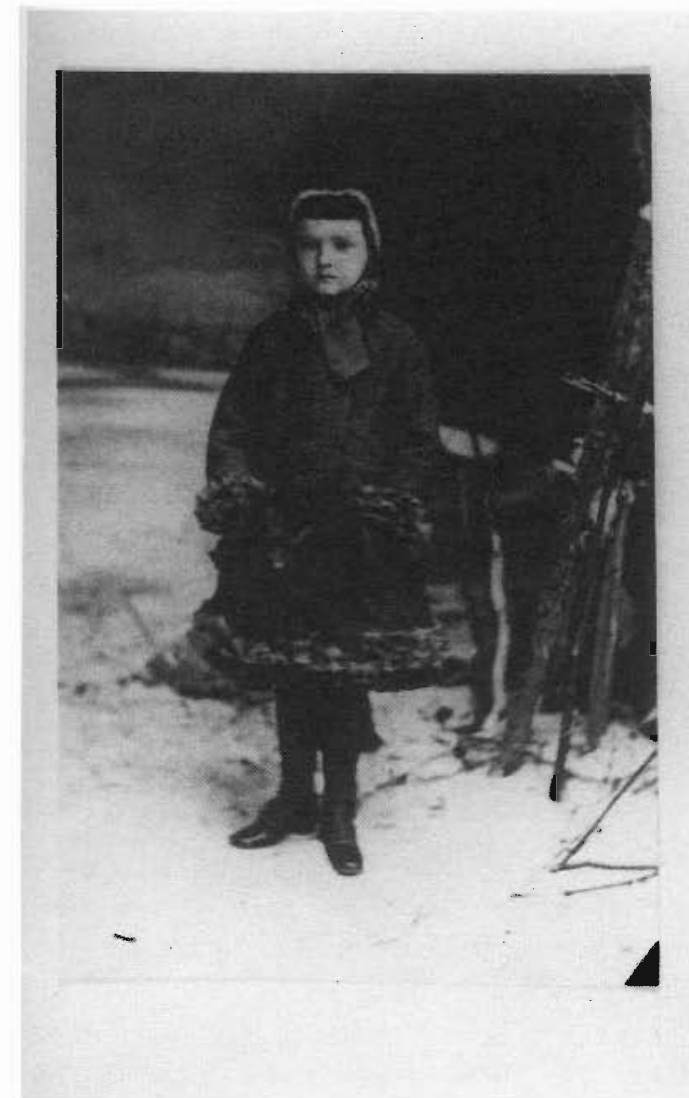

\author{
She looks so pretty and so trim \\ Like some grand lady, very prim \\ From head to feet; \\ I wonder if she ever plays, \\ Or is she pleased to spend her days \\ In looking neat- \\ With patient face she stands demure \\ Amid the snow, so calm that surely \\ Her ancestry was Quaker ... \\ Howe'er this be, she must be good \\ But were she not, her Mother would not dare \\ To shake her! \\ She's good, but from no sect she draws \\ Her dignity-it comes because \\ She knows she's blessed \\ With that more comfortable feeling \\ That o'er young women's hearts goes stealing \\ When nicely dressed \\ What e'er may come, I hope that she \\ May grow in grace and wit to be \\ A gentlewoman- \\ With kindly instincts, gracious ways \\ And ready wish to find some praise \\ For all that's human.
}

Limes eritten by J. S. Mctennan to his little sister in 1877. when he toas gn undergraduate at Trimity Hall, Combridge, England.

Figure 3. Isabella Christine McLennan, age 7 from an image accompanying a poem written by her brother John Stewart McLennan. (Notman Photographic Archives, McCord Museum of Canadian History)

In a letter written October 28, 1888 from Boston, Isabella says that she had been to a Chopin concert the night before. She found the music at Trinity Church "delightful" and marvelled that "the effect of the afternoon sun coming through the beautiful windows is most soothing and comforting. " Later she confesses her passion for music recitals:

Next Wednesday night we go to hear Coquelin ${ }^{14}$ and on Tuesday afternoon to a recital which Mr. Foote ${ }^{15}$ and Adamowski ${ }^{16}$ give. I am anxious to hear all the good music that $I$ can this winter. ${ }^{17}$

On November 5, 1888, she wrote home to her sister Alice, using plenty of the schoolgirl language of her day:

\begin{abstract}
My poor little 'housewife', you mustn't wear yourself out with your domestics. There is great excitement over the Elections tomorrow, all the girls are intensely interested and know so much about politics. I am a perfect buster, chronically hungry [and] ready to go to bed at eight.
\end{abstract}

And, in the same letter, a delicately phrased request for money:

Someday not too distant, when you happen to be in a pathetic vien [sic] of thought regarding me you can send me some filthy lucre - this is not an urgent call but only a suggestion. It is so much nicer to get money 'without writing for it', as the poet remarks. ${ }^{18}$ 
After seeing Isabella at Christmas in Montreal, her brother Francis wrote to their mother in Ottawa about Isabella on December 30, 1888:

You would be charmed with the growth of Belle in character, mind and manner - she is unusually clear headed, has a good memory and a considerable power of expression of ideas by no means ordinary among school girls. ${ }^{19}$

A mysterious letter addressed to "my darling Mamma" dated January 16th, 1889 has been firmly expurgated from the Commonplace Book. Isabella was in Boston at that date. ${ }^{20}$

Education for young women was considered appropriate only up to a point, and so far there is no record of her having attended college, so it is unlikely that she had any formal schooling after her year in Boston.

Neither she nor her sister Alice married. Richard Pennington, former University Librarian, McGill University, said that Isabella had been told in her youth that her health was delicate and that was one reason why she did not marry. ${ }^{23}$ As the daughter of a wealthy industrialist, there was no economic or social necessity for her to marry, and it seems probable that she was stronger in character than many potential husbands might have preferred at that time (Fig. 4). While it seems that she respected the customs of her class and time, there seems to be no doubt that her very erudite family encouraged her to have a mind of her own. Her sister Alice was considerably more frail and shy than she, and it is possible that Isabella chose to keep her company in the big family home after the death of her parents.

\section{ISABELLA McLENNAN: AGE FROM 19 - 34 (1889-1904)}

In the summer of 1890 , Isabella's father sold the house at 317 Drummond Street that had been bought for him by his brother John upon his father's second return from Chicago in 1867. Family reaction to this sale was very emotional as they had been very attached to the old house and nobody liked the prospective buyer.
Alice wrote to her brother Hugh on September 28, 1888:

Father sold our lovely lovely house.... and to that horrid old McInytre. Papa only asked him 50 cents a foot ... Papa thinks he did it in too much of hurry so we must try to cheer him up. Poor Mamma is in the depths. Fortunately, he doesn't want in for a year or more. When do you ever suppose we will get a house big enough to hold our precious things, too! 'Tis loathsome to think of Mr. Mclntyre going to Egypt and feel he will be sure to have a sunstroke out there.

Almost immediately, Hugh McLennan Sr, bought the house at 50 Ontario Street. It was occupied by the McLennan family until Isabella gave it to McGill University in $1942 .{ }^{22}$

Between the years 1881 and 1897 , the only five of her brothers to marry did so, and three of them (John, William and Alexander) produced eight daughters and three sons. However, during those years, one little niece died and her brother Hugh finally succumbed to tuberculosis, after being sick for many years ${ }^{23}$ (Fig. 5).

The seven years between July 1, 1897 to July 28 , 1904 must have been wrenching ones for Isabella and her family, as both parents and three more brothers died in that period. There were no marriages or births (on her paternal side) to alleviate this sadness. ${ }^{24} \mathrm{Her}$ father died just before the family was to go to Cape Breton on November 21, 1899. Her mother died on March 16, 1902 after a lengthy illness-she had not been healthy or pain-free since 1882 . Four lines were considered sufficient to inform the citizenry about her death. ${ }^{25}$ Isabella's brother William (Willie) died on July 28, 1904 and was buried in Florence, Italy. Her brother Alexander (Alex) died in a driving accident near Pincher Creek, Alberta on July 1, 1897 and was buried in Kentucky. Her brother Neil, the black sheep of the family, died in a shipping accident on December 13, 1897 and was buried in Namur in Belgium. ${ }^{26}$

In the relatively brief span of 17 years, sometime between her 31 st birthday in 1901 and her 47 th birthday in 1917, Isabella's hair turned completely white. She may have had a genetic predisposition to this, but it 


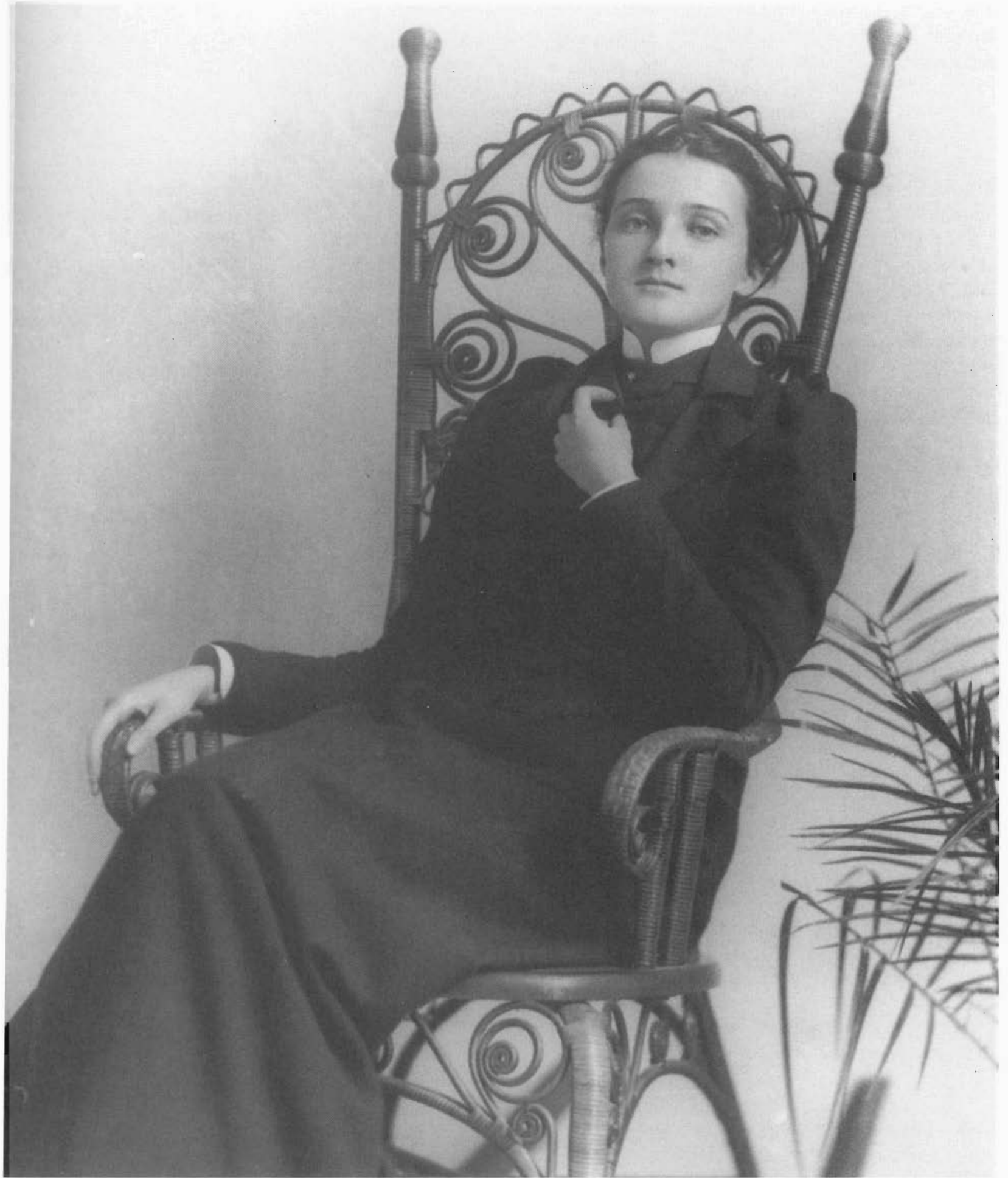

Figure 4. Isabella Christine McLennan, 1892. (Notman Photographic Archives, McCord Museum of Canadian History) 


\section{Isabella Christine McLennan}

also seems possible that those harrowing years that included so many family deaths, with all the worry and unhappiness associated with them, might have contributed to the early change of hair colour (Figs. 6 \& 7).

ISABELLA McLENNAN: AGE 34 TO 59 (19041929)

After Isabella's mother died in 1902, "the two sisters and Bart kept on the house." Bartlett (Bart) was a businessman and a golf enthusiast and equestrian. (Fig. 8) He hunted regularly at Montreal and spent two seasons in the south of Ireland. He loved polo and had a small but well-chosen racing stable. ${ }^{27} \mathrm{He}$ was annually listed as a member of several clubs - anywhere up to seven per year. His profession is not known, but Lovell's Street Directory listed him as the President of the Montreal Transportation Company in 1914-15. ${ }^{28}$

Isabella's brother, John S. McLennan, reports that

Alice became its [the McLennan house] guiding spirit, although the unit of these three people, each of them of strong individuality, was remarkable. She had early shown her capacity and with great devotion had been the guardian and, as far as might be, the deputy of our mother. The combination of extreme shyness, and lack of strength, made it impossible for her to take any part in the general social life of our circle, yet so great were her wisdom, justice and sympathy, that we all came to accept as final her decisions, even on matters foreign to her personal experience. Her position among us may be summed up in the phrase of a Scottish friend when she first visited us: 'I see that Alice is the hinge of this household.' Years only added to the supremacy accorded to her character and her capacity." 29

It seems, then, that Isabella and Bart both deferred to the wishes of their sister Alice at home. Isabella was often lumped together as a unit with Alice, as they were variously referred to as "the girls," "the Misses Mclennan," and later as "the aunts. "30
The McLennan family occupied the house until Isabella gave it to McGill University in 1942. Sometime during that period, its civic number was changed to 3480 , and the street name became du Musée. Bart used the house as a home base until his death in 1918, Alice lived there until she died in 1923, and Isabella did so until she moved to the Linton Apartments on Sherbrooke Street, probably around 1942. Isabel Durie a relative on their maternal side, lived there with the three around 1905-06 and was possibly absent in 1907 but returned in 1909. Their nephew, Hugh McLennan (born 1887, died 1915 at Yprès), lived there probably from 1907 until 1909 while he was at McGill. Around this time, John S. McLennan reported,

The house in Ontario Avenue was open to [Willie's children]. Hugh [John's son] and John Harrison McLennan [Alec's son] lived there during their McGill periods. They and Durie had the use of Bart's fine stable; and the visiting nieces had the advantage of the thoughtful and constant hospitality and entertainment of Bart and his sisters as they were entering society. ${ }^{31}$

The apparent omission of the girls' names from those who could use Bart's stable suggests that Alice and Isabella did not ride horses.

From 1911 until about 1928, there came a rather more eventful period for the family, as eight of Isabella's nieces and nephews married and produced sixteen children; among them, Isabella's great-nieces and nephews. ${ }^{32}$

Isabella's sister-in-law, John's wife Louise, died of appendicitis on January 27,1912 . John reported in his book that, barely seven weeks later,

we went to Europe, joining Bart and 'the aunts' on the 'George Washington' on March 23rd, a large party of seven-for Hugh (John's son) joined us at Tours-and a very happy one. ${ }^{33}$

In 1915, Bart, Isabella and Alice were present at the second marriage of their brother, John Stewart McLennan, to Grace Seeley Henop Tytus. That wedding took place in Sydney, Nova Scotia on January 


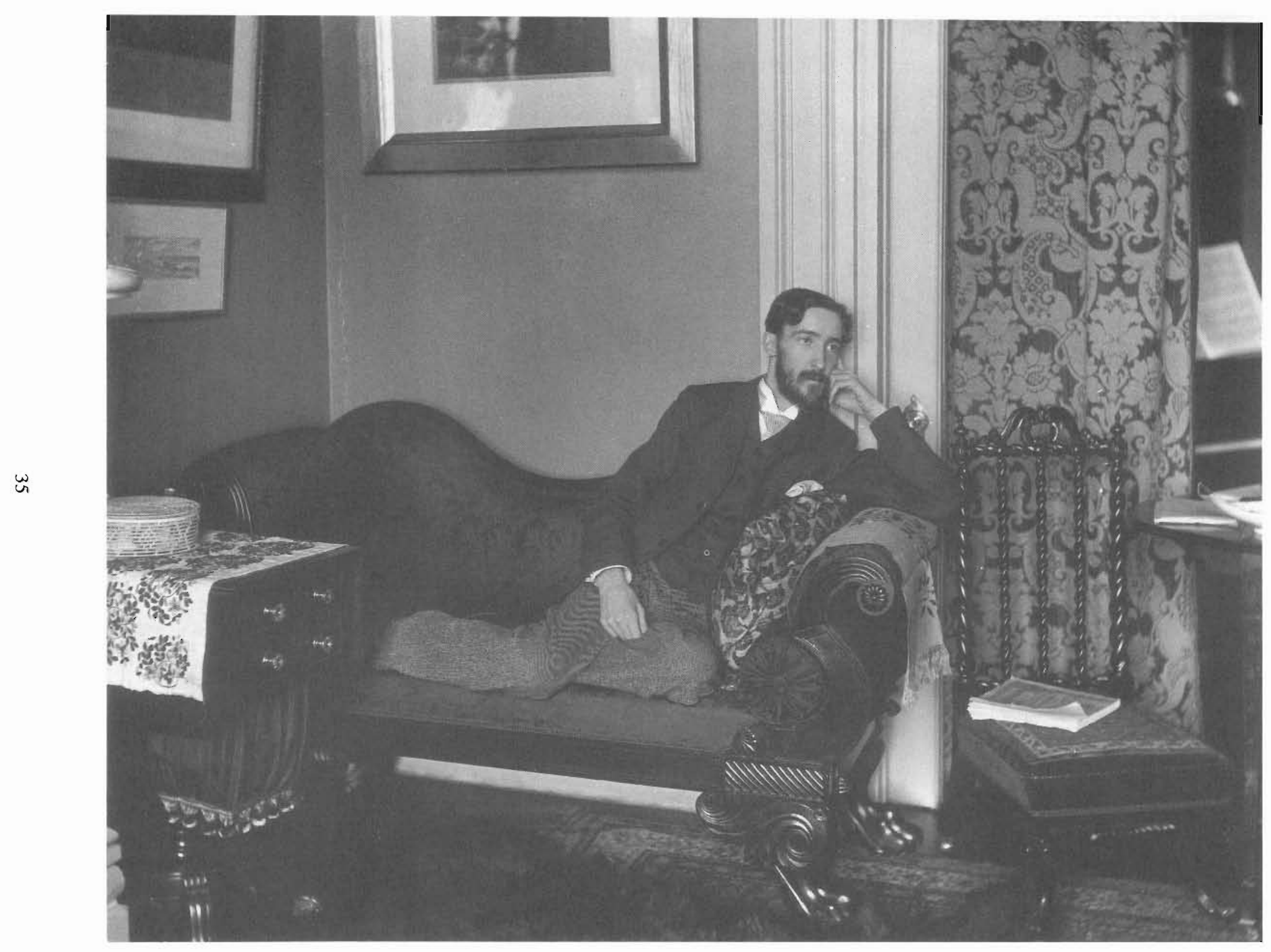

ई.

Figure 5. Hugh McLennan, 1892. (Notman Photographic Archives, McCord Museum of Canadian History) 


\section{Isabella Christine McLennan}

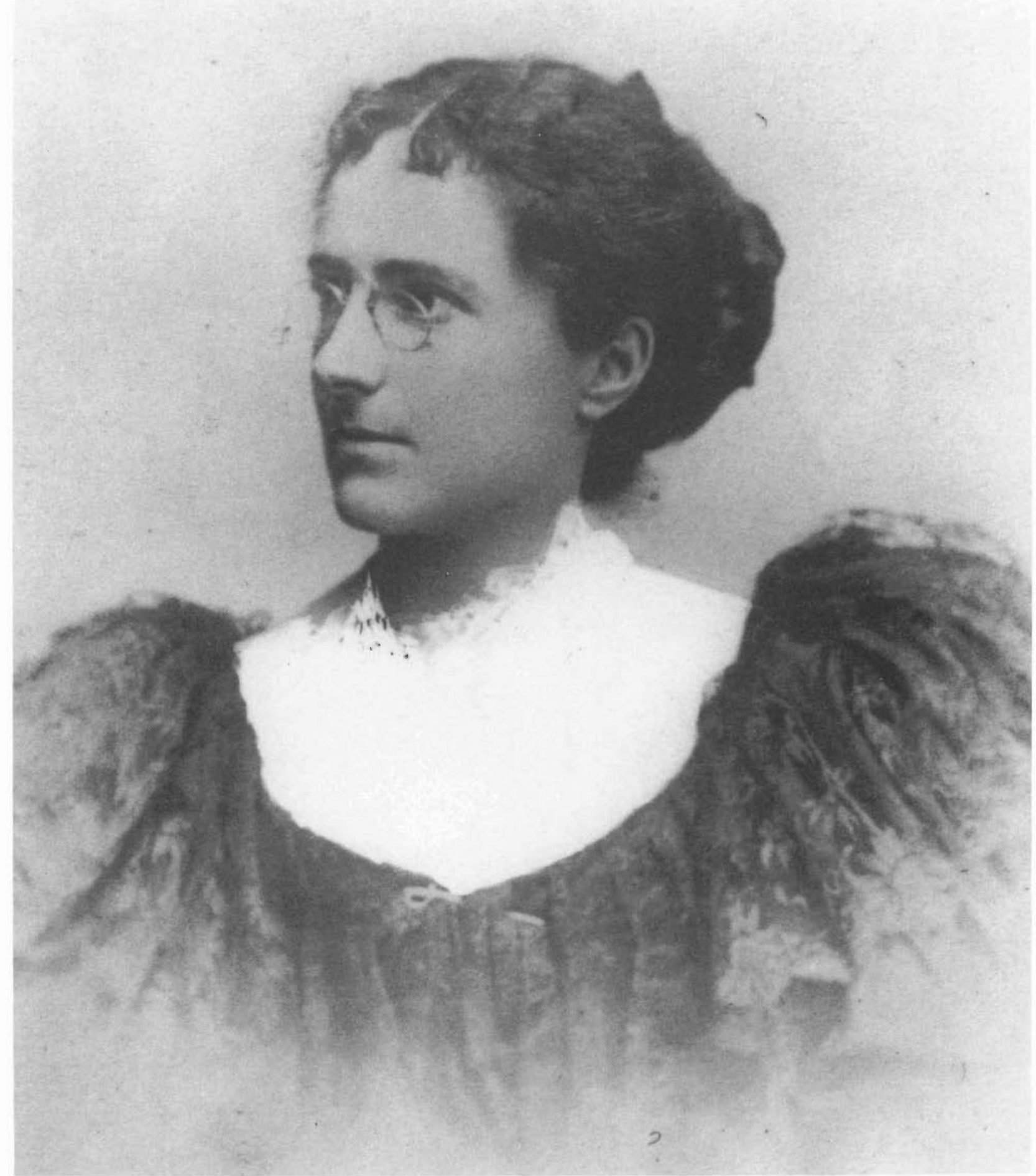

Figure 6. Isabella Christine McLennan, 1901. (Notman Photographic Archives, McCord Museum of Canadian History) 
Isabella Christine McLennan

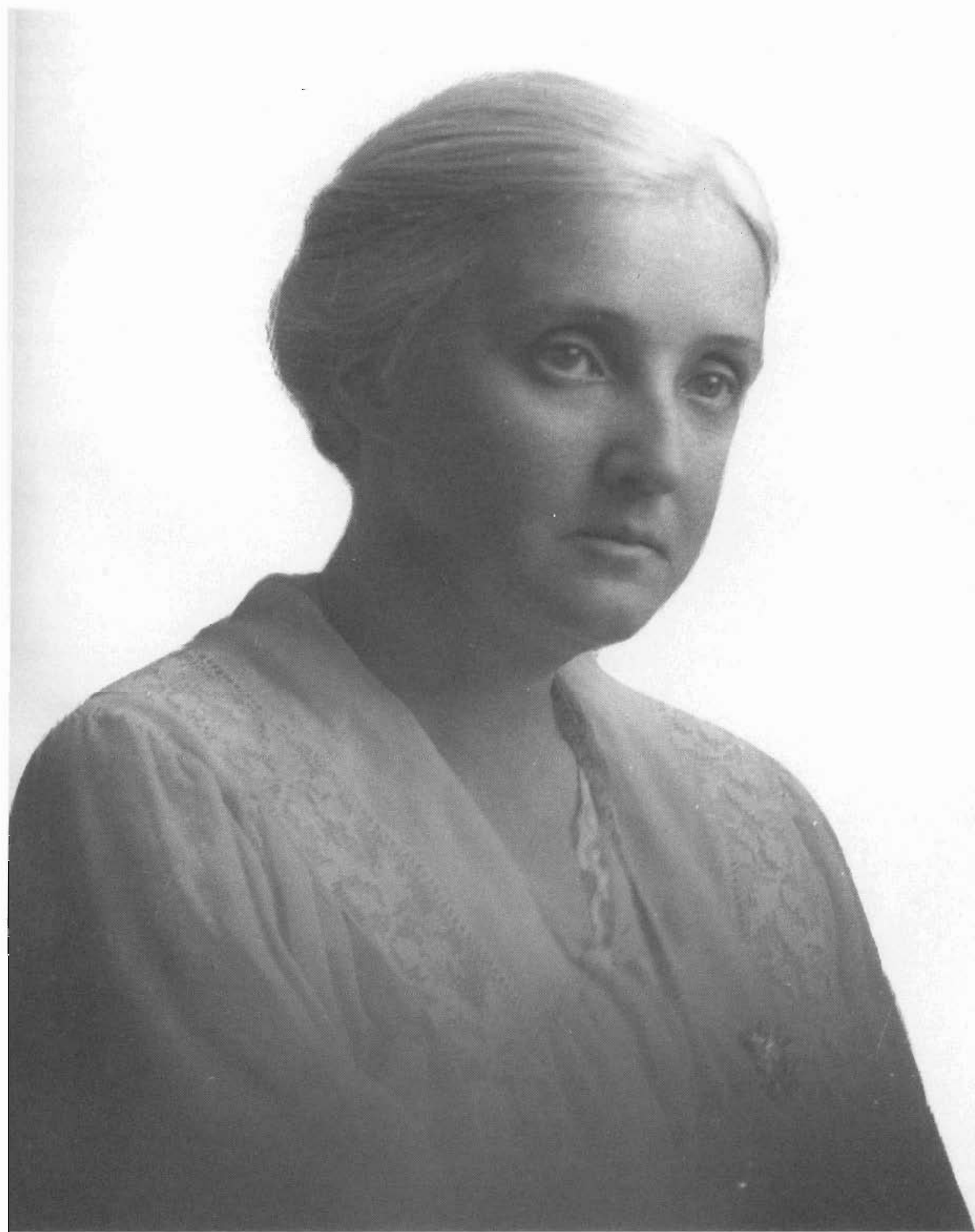

Figure 7. Isabella Christine McLennan, 1917. (Notman Photographic Archives, McCord Museum of Canadian History) 


\section{Isabella Christine McLennan}

7, 1915. Grace was from Boston, and the wedding was reported in about 12 papers-in Boston, New York, Nova Scotia and Montreal occupying about 6-8 column inches per article. Notable in the description was that the bride wore a black waist-length veil with a floral border! (This was probably because her previous husband had died only five months before. $)^{34}$

Lt.-Col. Bartlett McLennan, D.S.O., Isabella's closest brother in age, was killed at Armiens on August 3. 1918; he was a member of the 42nd Battalion, R.H.C. (Black Watch). A granite monolith was erected to his memory at Longeau and in 1926 it was brought back to Mount Royal Cemetery to stand among the memorials of his family. A beautiful stained glass window was installed over the communion table in the present Church of St. Andrew \& St. Paul, between 1921-24. It commemorates Bart particularly and those other members of his regiment who were killed during that War. ${ }^{35}$

In his Will made in 1915, Bart bequeathed the house at 3480 Ontario Avenue to Alice and Isabella. Alice died on June 3rd, 1923, at the age of 64 and bequeathed her share of the house and any other possession to Isabella. ${ }^{36}$

Isabella was always comfortable financially, largely as a result of careful family investment of her share of her father's considerable fortune, and particularly as a result of a sort of inbred frugality encouraged by her Scots forebears and practised by the entire family. A letter from one J.G. Cowan of Royal Trust dated November 7th, 1929 says that Isabella's net taxable income for 1928, surely the first year that such figures were calculated, was $\$ 83,553,23 .{ }^{37}$

It was only toward the end of her life that Isabella began writing her own cheques. Prior to that, she would write to the Royal Trust Company and ask them to issue a cheque and they would do the paperwork.

\section{ISABELLA McLENNAN: AGE 60-89 (1930-1960)}

In 1927 and 1930, Isabella was listed as living alone at 3480 Ontario Avenue. She would have been aged 60 then. ${ }^{38}$
It is probable that her closest friend, outside her family, was Ethel Hurlblatt, once Warden of the Royal Victoria College, who died before she did. There are no indications as to how long they were friends, but they were friends towards the ends of their lives. ${ }^{39}$

The widow of Isabella's great grandnephew, William $H$. Woodward, informed the author that Isabella, William Durie McLennan and his wife Gyneth Wanklyn, William $\mathrm{H}$. Woodward and his parents all went on a trip to Atlantic City, New Jersey, sometime in the nineteen-thirties. She also said that her husband had visited his "Auntie Belle" many times in Montreal, and specially noted that he was there for the U.S. Thanksgiving in $1940 .{ }^{40}$

Sometime between January 17, 1940 and November 11, 1942, Isabella moved from her Ontario Street home to apartment 81, The Linton Apartments at 1509 Sherbrooke Street West. ${ }^{41}$

Isabella took every opportunity to spend at least the months of July and August of every year outside the city. After her family sold their summer residence in Cartierville, sometime between 1924 and 1930, Isabella began visiting friends or travelling alone to various places not terribly far from Montreal. In the summer of August 1939, she was at Pecketts-on-Sugar in Franconia, New Hampshire, from where she mailed a picture postcard. In 1945, she was planning to spend the summer in North Hatley, Quebec. In 1948, she told Dr. Lomer of McGill in a letter that she was going to Old Hill, Lac Echo, Lesage, Quebec from June 30th until the fall. ${ }^{42}$ In the summer of 1955 , she stayed at Northeast Harbour, Maine and in Maine again the following year. ${ }^{43}$

For the last sixteen years of her life (i.e. from sometime in 1944 until her death), Miss McLennan needed the care and companionship of a private duty nurse named Kathryn B. Neaves, who graduated from the Royal Victoria Hospital School of Nursing in 1923 and was from Nova Scotia. ${ }^{44}$

The Montreal Gazette reports that Isabella Christine McLennan died on Monday, April 4, 1960. The Royal Trust and The Montreal Star agree that she died on Tuesday, April 5, 1960. She died in her 89 th year at 


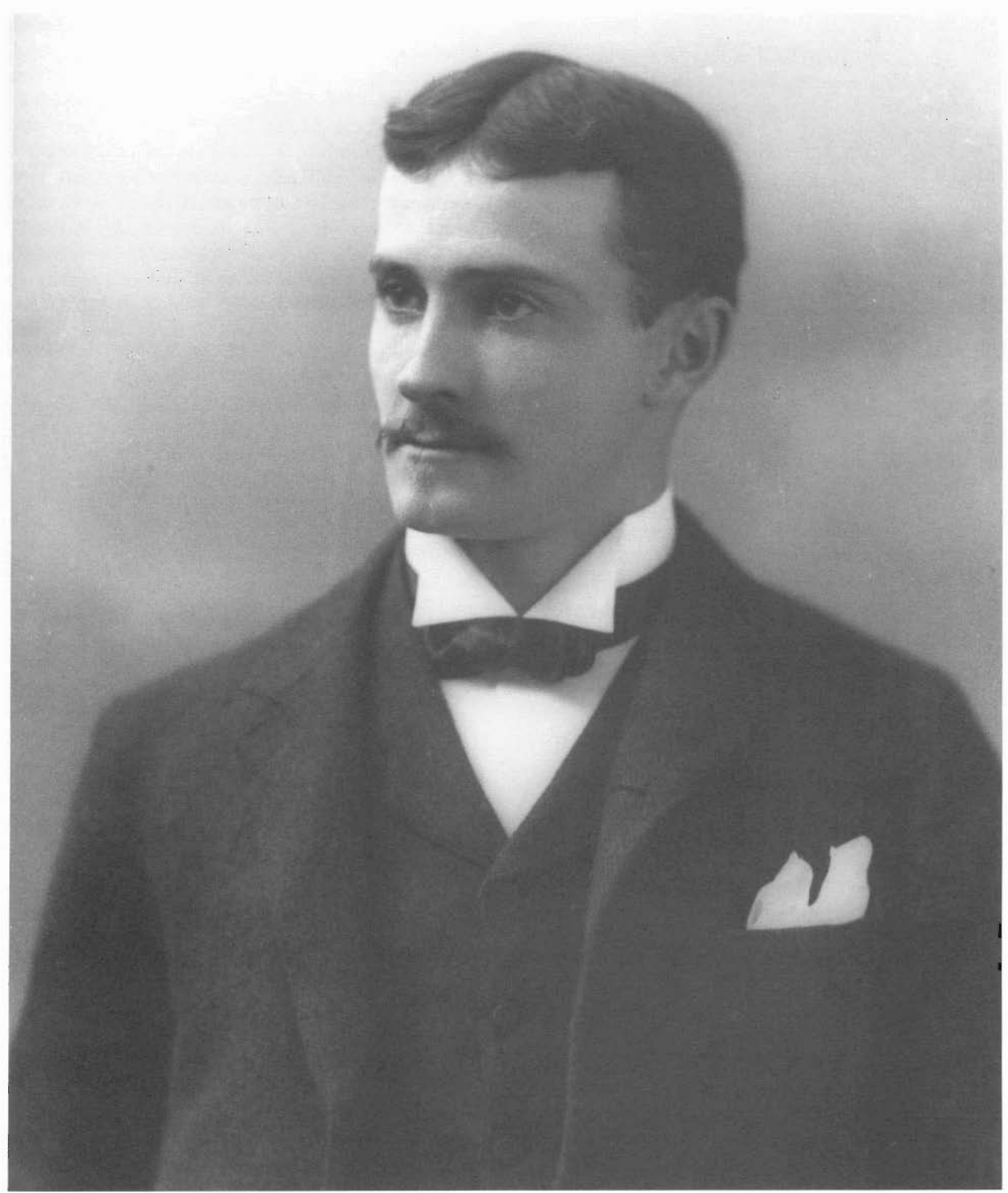

Figure 8. Bartlett McLennan, 1892. (Notman Photographic Archives, McCord Museum of Canadian History) 
the Royal Victoria Hospital and was buried in the Church of St. Andrew and St. Paul on April 7th, $1960 . .^{45}$

\section{ISABELLA MCLENNAN: CONTRIBUTIONS TO McGILL}

\section{McLennan Travelling Libraries}

Isabella's father, Hugh McLennan, started the McLennan Travelling Libraries in 1899, and this was to remain a chief interest of hers for over fifty years after his death. They were first conceived by former McGill Libraxian, Charles Gould, a great friend of her father's. ${ }^{45}$

Under this library system, boxes of about thirty varied books were shipped all over Canada to places where no libraries and few books of any kind existed. In these remote areas, books were seized eagerly by many of the residents, and passed from one to the other until most people had read all they had wanted to, then they were shipped back, to be replaced by a new selection.

The Travelling Libraries operated initially in rural Quebec, but in McGill University, vol. II, Dr. Stanley Frost says,

.. The service proved so popular that it soon went far beyond provincial boundaries. In the Yukon, Dawson City was supplied by rail; in Newfoundland, Battle Harbour by rail and sea; northern Ontario, the Gaspé Peninsula, and the area north of Ottawa were regular beneficiaries. A local church, a Woman's Institute, a rural school, were typical recipients of the boxes... From the Magdalen Islands to the far west, the travelling library service reflected McGill's sense of responsibility for all of Canada, and of its role as a national institution. ${ }^{47}$

On January 11, 1911, Isabella, her brothers Joho, Francis and Bart, her sister Alice, her niece Alice and her nephew William Durie McLennan met with Governor John Fleet of Nova Scotia and Notary Public
John Fair of Montreal, to establish the Hugh McLennan Fund for the McLennan Travelling Libraries. The McLermans donated capital stock shares and cash to a value of $\$ 20,000$, given "unto the Royal Institution for the Advancement of Learaing. "48

The Travelling Libraries were first supported by the McLennan family and administered by McGill University, and later supported to a large extent by Isabella herself. She funded the McLennan Travelling Libraries on semi-annual basis and occasionally by special request. This included paying the salary of its first Director, Miss Elizabeth G. Hall, which was then $\$ 480.00$ per year. ${ }^{49}$

The Travelling Libraries were run almost exclusively by women. Elizabeth $\mathrm{G}$. Hall ran it from 1901 to 1936; Miss Dorothy Bizzey until 1940; Adele de G. Languedoc from 1940 to 1945: Frances Maunsell in 1952 and Kathleen Clynes from 1954 to $1969 .^{\text {so }}$

In May 1933, Isabella wrote to Dr. Lomer that she and her brothers would have to reduce expenditures on the I.ibraries, curtailing work with the schools. ${ }^{51}$

She gave the Travelling Libraries $\$ 5,000$ for its first Bookmobile in 1950 , and paid over $\$ 1,600$ to have it fixed after it was in an accident in 1952. She donated $\$ 7,500$ for another Bookmobile in 1956. ${ }^{52}$ Throughout almost two-thirds of her life, she kept the Travelling Libraries running almost single-handedly through her donations.

The outreach libraries were able to continue, with contributions from the Quebec government until about 1976 , but in 1978, the functions of the Libraries were absorbed by the programme of the Bibliothèque centrale de l'Estrie. They inherited the books and the historical material was left with the McGill Archives. ${ }^{53}$

\section{Other McGill Contributions}

At least two and perbaps four of Isabella's brothers had graduated from McGill, William had been a librarian and her father had had good friends there. Consequently, Isabella established a lifelong attachment to the university, the libraries, their directors and staff. She maintained close ties with the McGill Libraries and their directors and staff. When Miss Elizabeth G. Hall 


\section{Isabella Christine McLeman}

retired as Director of the McLennan Travelling Libraries in June 1936, Isabella sent a financial donation for the purchase of a farewell present. She also attended the afternoon tea given in Miss Hall's honour and planned to send some fresh flowers from her garden for the occasion. In February 1937, she invited all twenty members of the McGill Library staff to tea on a Saturday afternoon, and sixteen of them accepted. ${ }^{54}$ There is a suggestion that this was an annual event for a number of years.

The McLennans were a very generous family but not one to broadcast their philanthropy. They never appeared in public handing over six-foot cheques to their beneficiaries, and Isabella was never photographed with any of the library vans she donated.

In 1928, when the McLennan family established the Hugh McLennan Memorial Scholarship in Architecture in memory of their nephew who was killed at Yprès during the First World War, a sufficient sum of money was donated to yield an income of $\$ 1,000$ for a travelling scholarship to be awarded annually to "that student who, during his course, has shown the greatest capacity in the solution of problems and promise of creative ability, rather than in draughtsmanship. ${ }^{155}$

There were several conditions to winning this scholarship, some official and some unofficial. The official ones included submitting sketches and studies after at least six months in Europe. An unofficial one was to have tea with Miss McLennan at her apartment at The Linton before and after the trip.

David Bourke, now McGill's Secretary-General and Architect of the McLennan Library, who won the Travelling Scholarship in 1954, said that his bride accompanied him on the six-month trip. He was required to take photographs on his trip rather than do sketches. When he had tea with Miss McLennan, she explained that this was because she had learned that some previous winners bad been doing their sketches from postcards and reference books on board the ship coming home, which rather defeated the purpose of the scholarship! He remembered that Miss McLennan had spent some time in Venice and described her as "a lively lady and sharp as a tack." He had kept in touch with her after he came home and recalls her open and generous nature. She would often give him tickets to a ball or some other event she could not attend. ${ }^{56}$
In October 1942, Isabella donated the family home at 3480 Ontario Avenue to McGill University, "for any academic use which the University wishes to make of it. " ${ }^{57}$ The house lay idle for a few months, and then was used as a residence for male civilian students. Beginning in the fall of 1944 , it was used as an annex to the Royal Victoria College, as a women's residence.

\section{Located just behind the Art Gallery on} Sherbrooke Street, the house is situated on spacious gardened grounds. It has ivycovered stone walls, a sunken garden and a fountain. ${ }^{58}$

In addition to the house, she gave McGill a small collection of paintings and other artwork. She also made arrangements to give the McGill library a large and varied collection of books and furniture which included clocks, bronzes, a marble statue, tables, a sofa, chandeliers, curtains, chairs, maps, rugs, bookcases and pictures. ${ }^{59}$

Other areas of McGill benefitted substantially from Miss McLennan's generosity. She established the Isabella McLennan Prize in the School of Architecture, the Isabella McLennan Scholarship Fund in Library Science, the Elizabeth G. Hall Memorial Scholarship Endowment and also donated generously to the Friends of the Library Fund. ${ }^{\infty}$

In May of 1947, Isabella established "The Gould Lecture Fund" with a cheque for $\$ 5,000$ in honour of Mr. Charles Henry Gould, who was the McGill Librarian from 1893-1919 and a good friend of her father. It was he who inspired Hugh McLennan to start the Travelling Libraries in 1899, and he who inaugurated professional library training in Canada in 1904. The fund provided $\$ 500$ a year until the fund was exhausted to give students the opportunity to hear outstanding librarians speak. ${ }^{61}$

The McLennan family were great readers and collectors of books. William was a writer and McGill Librarian; Francis eventually willed a large collection of his books to McGill University. ${ }^{62}$

In a June 1956 letter, the then current University Librarian described for Miss McLennan four treasures of Canadiana which the University had acquired with 
funds from the Friends of the Library, which was one of her regular beneficiaries. They were:

The original Proclamation of Canadian Federation (it came from Lord Harmsworth's collection); the first edition of the first book about the discovery of Hudson's Bay (published in 1611); the earliest book about the boundary problem of Acadia which was so long a dispute between France and England; and the first English translation of the first Spanish work that described the conquest of Mexico. ${ }^{63}$

The 1960-61 McGill Annual Report says that her estate endowed the McLennan wing of the Redpath Library with $\$ 573,655.73$ as "funds for restricted purposes." The Auditor's report in the same Annual Report says that her bequest was $\$ 703,655.53 .{ }^{64} \mathrm{Dr}$. Stanley Frost says that she "bequeathed McGill over \$1 million for library purposes. "65

Richard Pennington, McGill's Librarian from 1947 to 1965, has indicated that Miss McLennan had told him that "she intended to remember the Redpath Library in her will, and she added, 'It will be to buy books. Not for bricks and mortar.' A remark I remembered when the University diverted her bequest to bricks and mortar. "166

\section{ISABELla McLENNAN: A PRIVATE PERSON}

What was Isabella McLennan like as a person? When Richard Pennington was University Librarian at McGill, he used to have tea with Miss McLennan about once a year. He described her apartment at The Lintons as very elegant and in excellent taste, "quite unlike the apartment of a "vieille dame.' When he was being escorted out after one of their teas, she would give him, as unobtrusively as possible, a cheque to be used for library books. He said she would have preferred that her entire bequest be used for books, but at the time, space to display and store books was far more urgent and she was eventually persuaded to permit McGill to handle the bequest as it wished within certain less confining parameters. ${ }^{67}$ The McLennan Library, which was officially inaugurated on June 6th, 1969, was the result.
Miss Alison Cole was a junior librarian at McGill in the late 1940s and early 1950s. She remembers baving tea once with Miss McLennan and Richard Pennington at The Linton apartments. She says that Miss McLennan was a very private person, very dignified and proper, but terribly shy and there was not much conversation at that tea. During such visits, Miss McLennan would examine some of the more interesting book acquisitions the Library had made. One of her interests was the Commedia dell'Arte, a history of which was the subject of one book Miss Cole remembers. McGill has an exceptional collection of books about the Commedia dell'Arte, one of which is a collection of pictures created entirely out of coloured feathers; these books are displayed annually for students in the Department of Italian. Occasionally, Miss McLennan would come to the Redpath Library in a chauffeured car with her companion to examine a special acquisition. Miss Cole said that Miss McLennan would sometimes have spare tickets to a theatre performance, which she would give to the Librarian's secretary and say she would like some of the staff members to use them. She always made sure that they went out for a good dinner first, sometimes with her companion, but Miss McLennan only went once. ${ }^{* 8}$

One great nephew, Hugh McLennan, now a professor in British Columbia, remembers her from his youth as "a somewhat aloof, very kindly lady who was definitely the head of the local clan. ${ }^{169}$

John Stewart McLennan, a nephew born in 1915 , was the only child of Isabella's brother John's second marriage, to Grace Seeley Henop Tytus, which eventually ended in divorce. As a boy, John Stewart stayed with his mother in the United States and only saw his father occasionally for an afternoon. He came to know his father better in Montreal and Nova Scotia when he was eighteen years old. He has recalled that his relationship with Isabella had been extraordinarily complicated because of the difficult and sad proceedings between Grace and his father.

He felt that there was no love lost between his Auntie Belle and his mother and that Isabella bad only abided him on sufferance. Therefore, while his physical descriptions of her match those of other people who knew her, the love and affection that she apparently showed others was lacking in their relationship. He said 


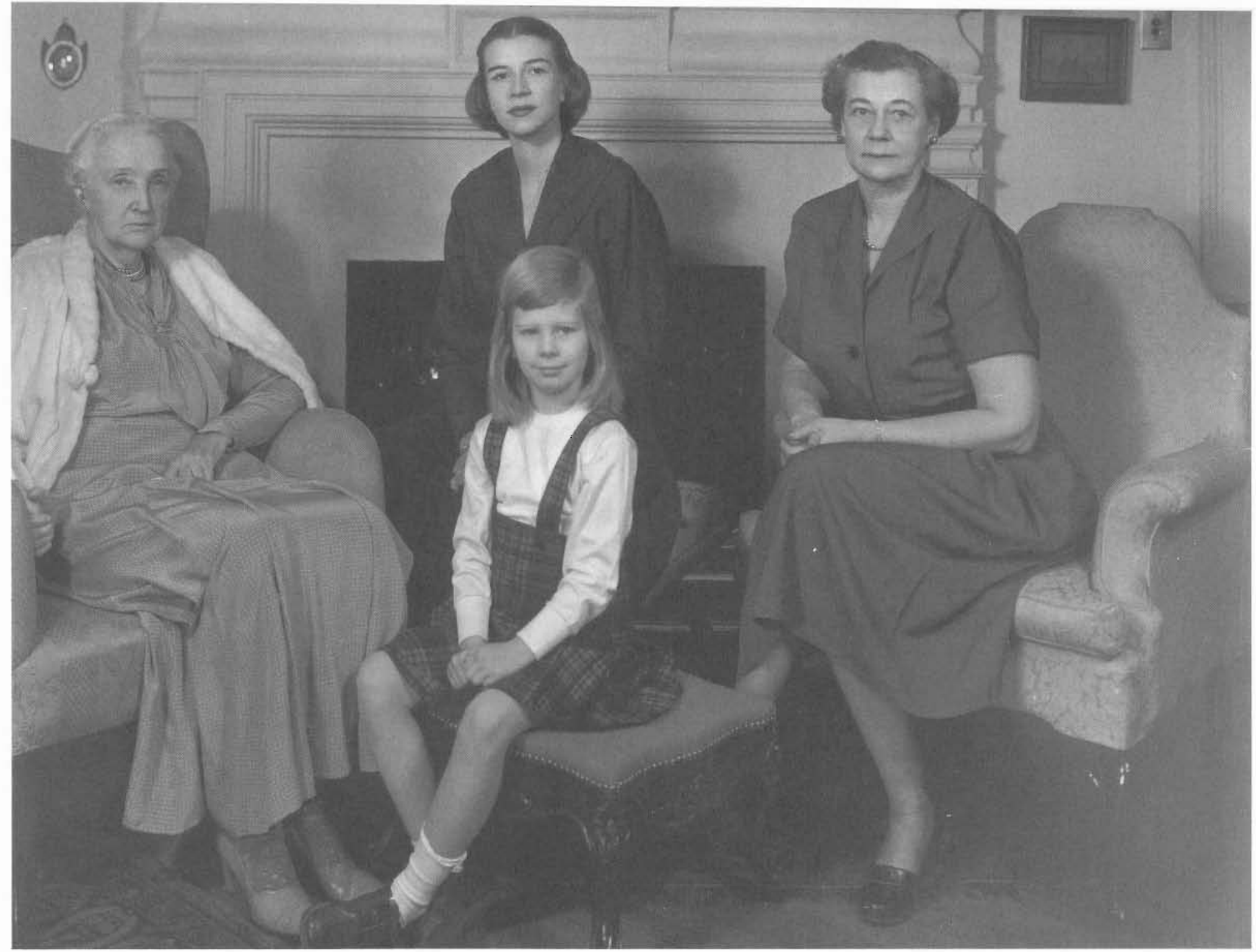

Figure 9. From left to right: Isabella Christine McLennan, Isabella McLennan McMeekin Dulaney Todd; Isabella's great-niece; and Isabella Stewart McLennan McMeekin; her niece; Centre: Isabella McMeekin Dulaney; great-great niece. 1952 (Notman Photographic Archives, McCord Museum of Canadian History) 


\section{Isabella Christine McLennan}

she was extremely beautiful, severe, almost icy, formidable, and extraordinarily loyal to his father, John Stewart McLennan. She was always politely kind to him and hospitable to him when he visited the house on Ontario Street and he retains many happy memories of the bouse. She didn't honestly intimidate him, he said, but she was physically compelling and he felt unswervably on his good behaviour when he was near her. When he saw her, she was small, and immaculately but severely dressed. He felt she had been repressed by the position she'd held in her family. When he knew her, she held acid opinion on various family matters. ${ }^{70}$

The men in Isabella's life were many and strong. Her father was a respected and successful industrialist in the grain trade who ran a firm but loving home.

Her four older brothers were well respected members of their professions by the time she was old enough to be considering the search for a suitable husband, if indeed she ever did. Men around her own age may have considered her a trifle daunting with such men to emulate. Her mother was not really well enough to orchestrate a proper and serious courtship for her, although her sister Alice might have attempted that, being eleven years older. There may have been an unspoken agreement to stay single and keep her sister company, since they were such a closeknit family. If there was any romance or courtship in Isabella's life, it is lost to us thus far.

Margaret W. Westley says of Montreal women of the period:

The women of prominent families were neither trained nor expected to do anything useful, except to organize the household servants. Having a large number of servants, they had a great deal of time on their hands. Lady Drummond, Lady Hingston, Mrs. Herbert Molson, and many athers used this time to organize and run more than a hundred and fifty church, social, and charitable organizations. Others devoted it to the social whirl, which became the centre of their lives. ${ }^{71}$
The McLennan family was involved in Montreal society life to the extent of having Tuesdays assigned as their Visiting Day until at least 1913. The only known early photographs of Isabella were taken by William Notman for her engraved visiting cards, which she would have left at every home she visited. The visiting system meant that a family (mostly the ladies) would stay at home between 11 a.m. and 6 p.m. on their designated days (once, twice or four times a month) and various friends and acquaintances would visit them. On the remaining days, the family members would visit the other people of their set. In the absence of ubiquitous telephones, this was a reliable way of assuring that people would be where they were expected to be at a given time. Sherry and other light refresbments were served during these visits. ${ }^{72}$

What did Isabella do with her time? It seems likely that she enjoyed reading, especially about artistic subjects, as well as collecting art of various kinds, but there is no evidence that she enjoyed doing any kind of handwork, with the possible exception of gardening.

Isabella's social life would have varied according to when and where she was travelling, family illness or worries, the demands and events of the First World War (which had many society ladies' energies placed in volunteer work) and time constraints.

According to the Dau Blue Books for Montreal, Ottawa and Quebec City, Isabella, her mother, her sister Alice and her brother Bartlett belonged to several different Montreal clubs between 1899 and 1930. However, Isabella's shyness seems to have dictated that she would assume only honorary positions because of her generous financial donations to them. These clubs included the St. Andrew's Society, the Ladies' Morning Musical Club and the Women's Canadian Club. ${ }^{73}$

Her family was a very close one. One brother, John, lived part of his life in Nova Scotia and was a Canadian Senator. Another brother, Hugh, lived in various sanatoria and rest homes because of his tuberculosis. Much of her mother's family was in Ottawa. Since the various members of the family travelled frequently, both in Canada and abroad, it is safe to assume that Isabella visited back and forth between her local relatives, and we know that she went to Europe fairly 


\section{Isabella Christine McLennan}

frequently. These trips would not, however, have been the two-to-three week brief excursions to one or another country that we do now. Rather, since a steamship ocean trip took up to a week, these trips would more likely have taken two to four months, possibly once a year, or at least every couple of years. These trips probably included an opera, theatre or social "season" in a popular cultural centre such as Venice.

Attendant on any such long-term trip would have been the acquisition of a suitable wardrobe, with all the necessary choices of fabric, styles and accessories, and all the fittings and packing. Even the annual removal to the summer residence of the family and staff would have been a major undertaking. Any single day required three or four changes of clothing.

The family did have gardeners and inside servants to do most of the heavy work such as cleaning, cooking and laundry. But there would still have been plenty of planning and organization to do, as well as the general management of a 12-room house and household, which would naturally do a fair amount of entertainment of both family and friends. Isabella had a secretary from time to time in her life.

There are sixty-one births, marriages and deaths on record in Isabella's immediate family during her lifetime. Add an equal amount for friends, acquaintances and staff, and it adds up to a sizeable number of special occasions. For each birth there would have been a christening, for each wedding several parties and for each death a funeral, each of which required suitable clothing and occasional travel. Then there were the usual annual celebrations, birthdays, farewells and other special occasions, for which arrangements were necessary. Then there were the weekly "At home" days and regular and special visits, as well as the annual St. Andrew's and Hunt Balls, theatre and orchestral presentations and some church life.

Given all this potential for social life, it is likely that Isabella was kept quite busy keeping up with all of it. She was interested in various hospitals and other social concerns, but does not seem to have worked on any Boards or committees for them, but rather is listed as a regular financial donor.
There seems to be little doubt that Isabella was a strong character, for everything we know about her, from her father's affectionate description of her expressive powers after her year in Boston, to the way that she later firmly managed her money and other assets, to her great nephew's comment that was "the head of her local clan," points to this.

We can see from her photographs that she was attractive, even beautiful. It is not fair to judge her by the expressions she wore in some early photographs, which sometimes appear a little pouty or even supercilious; people were not given to grinning broadly for photographs in those days quite as much as we do now. Having a photo taken was a momentous and serious as having a passport picture taken is today, and the acceptable facial expressions were about as sombre. There may be other photographs of her, but the only other known one was taken when she was 82 as the eldest of four generations of her family (Fig. 9).

From various correspondence and conversations, it seems evident that Isabella was a well-loved and greatly respected sister, aunt, great-aunt and a little-known supporter of many public and private charities. She was a strong character but a rather shy and reclusive person except where her family was concerned. She was generous, but gave judiciously and where the money was most needed, to both men and women. She had a definite preference for rewarding creative rather than technical ability in scholarship, and preferred books over buildings.

\section{Notes}

1. McLennan, John Stewart, Hugh McLennan, 1825-1899, Montreal: privately published, 1936, p. 57.

2. McLennan, Hugh Stewart, Commonplace Book, 18831889, found in Rare Books Department of McGill's McLennan Library, with McLennan family papers.

3. McLennan, John Stewart, 1936, p. 57.

4. Letter from father to unknown correspondent, probably a Durie in-law, dated December 3, 1870. McGill Rare Books Department, MS 238/3.

5. McLennan, John Stewart, 1936, p. 56 \& 57.

6. McLennan, John Stewart, 1936, p. 57.

7. Commonplace Book, 1883-1889, and McLennan, John Stewart (1936), passim.

8. McLennan, John Stewart, 1936, p. 62.

9. McLennan, Hugh Stewart, Commonplace Book, 1883 1889, Letter from Isabella dated July 13th, 1888. 


\section{Isabella Christine McLennan}

10. Commonplace Book, 1883-1889, Letter from Isabella Stewart MeLennan dated August 24th, 1888.

11. Commonplace Book, 1883-1889, Letter from Alma Stuart written in September 1888.

12. Commonplace Book, 1883-1889, Letter from Alice to their brother Hugh (Hugo) dated September 28th, 1888.

13. Commonplace Book, 1883-1889, Letter from Alma Stuart dated November 8th, 1888.

14. Constant-Benoit Coquelin was a French actor who started at the Comédie Française, and went on a long tour to Europe and America which ended in 1892 . In 1900 he toured with Sarah Bernhardt. He was a "big man with a fine voice and presence." (The Oxford Companion to the Theare, ed. Phyllis Hartnell, 4th ed., Oxford: Oxford University Press, 1983). 15. Arthur (William) Foote was an American organist and composer who was organist at the First Unitarian Church in Boston at the time that Isabella saw him. He composed the work that Isabella might have heard that day, "The Wreck of the Hesperus" by Longfellow, an adaptation for chorus and orchestra, which was new in 1888 (The New Grove Dictionary of Music and Musicians, ed. by Stanley Sadie, Vols. 1, p. 51 \& VI, p. 424, London: MacMillan Publishers Limited, 1980).

16. Tymoteusz Adamowski was a Polish violinist and composer who emigrated to the U.S.A. in 1879, where he was a member of the Boston Symphony Orchestra when Isabella saw him. No information is avallable on Madame Utassi (The New Grove Dictionary of Music and Musicians, ed. by Stanley Sadie, Vols. I p. 51 \& VI, p. 424, London; MacMillan Publishers, 1980).

17. Commonplace Book, 1883-1889, Letter from Isabella dated October 28th, 1888.

18. Commonplace Book, 1883-1889, Letter from Isabella dated November 5 th, 1888.

19. Commonplace Book, 1883-1889, Letter from Francis to his mother dated December 30th, 1888 .

20. Commonplace Book, 1883-1889, Letter dated January 16 th, 1889.

21. Letter from Richard Pennington to Prof. Peter F. McNally, April 11, 1995.

22. McLennan, John Stewart (1936). pp. 59, 69-72.

23. MeLennan, John Stewart (1936). pp. 95-99.

24. McLennan, John Stewart (1936). pp. 73, 95-99; also McLennan Family tombstones, Cote des Neiges Cemetery, Montreal.

25. Montreal Daily Star, March 19, 1902, p. 9.

26. McLennan, John Stewart (1936), passim.

27. McLennan, John Stewart (1936), p. 85-87.

28. Lovell's Street Guide, Montreal, 1914-15, (Montreal: Lovell's, 1915), p. 1616.

29. McLennan, John Stewart (1936), p. 87.

30. McLennan, John Stewart (1936), p. 88; McLennan/Tytus newspaper wedding reports, McLennan family scrapbooks, McGill Rare Books Department.
31. Dau's Society Blue Book for Montreal, Ottawa and Quebec: A Social Directory, Vol. V, VI \& VII, 1905-06, 1907 and 1909, and McLennan, John Stewart (1936), p. 91. 32. McLennan, John Stewart, (1936), pp. 95-99 \& passim.

33. McLennan, John Stewart, (1936), p. 87, 93.

34. Photocopy of McLennan family scrapbook, MeGill Rare Books Department (Cutter 149, + M222m).

35. McLennan, John Stewart (1936), p. 99-100; McLennan family plot, Cote des Neiges Cemetery and the Church of St. Andrew \& St. Paul; Notman photo 20,162.

36. McGill Archives, Record Group 4, Container 0493, file 06856. Also, McLennan family plot, Côte des Neiges Cemetery.

37. McGill Rare Books Department, McLennan Family records, MS 238/7.

38. Dau's Montreal \& Ottawa Blue Book, 1927 \& 1930.

39. Isabella C. McLennan, Last Will \& Testament, dated April 8, 1952, p. 3.

40. Letter from Mrs. William $H$. Woodward to R. Turpin dated December 31, 1994.

41. Originals and copies of letters to and from I.C. McLennan at both addresses, McGill Archives, Record Group 4, Container 0248, file 4004.

42. McGill Archives, Isabella McLennan's letter of June 30, 1948 to Dr. Lomer, in Record Group 4, Container 0248, Box $1209 \mathrm{~A}$, file 4004 and 4006.

43. Letter from E. Bancroft of McDonald, Currie dated June 20th, 1955 in McGill Archives, Record Group 40, Container C-1, Box 2063C, File 522-3, and letter from H.R.C. Avison dated September 28, 1956, in which Isabella invited him to visit her in Maine, in same location, file 522-2.

44. McGill Archives, Record Group 4, Container 0263$2068 \mathrm{C}$, File No, 7401.

45. Montreal Star, Thursday, April 7th, 1960, Obituaries. Neither of the hospitals could be persuaded to let me browse in their archives for further information as they both complained of being short-staffed in that department. McGill Archives, Record Group 4, Container 263-2068C, File 7401, and Montreal Gazette, Friday, April 8th, 1960.

46. Hall, Elizabeth G., The McGill Travelling Libraries, The McGill News, June 1925, p. 19.

47. Frost, Stanley Brice, McGill University for the Advancement of Learning, Vol II, 1985-1971, p. 73 and Note 29 for that chapter.

48. McGill Archives, McLennan Travelling Libraries Microfilm, film MF-1652, reel 2, passim.

49. McGill Archives, Letter from Isabella McLennan to Dr. G.R. Lomer dated May 29th, 1933 in Record Group 4, Container No. 248, file 4004, "H. McLennan, Travelling Libraries."

50. Letter in McGill News "Letters," Vol. 48, no. 2, May 1967, p. 2, and McLennan Travelling Library records, passim, and McGill University Archives, Microfilm M/F 1652 , reel 1 . 
51. McGill Archives, Letter from Isabella McLennan to Dr. G.R. Lomer dated May 29th, 1933 in Record Group 4, Container No. 0248, file 4004, "H. McLennan, Travelling Libraries."

52. McGill Archives, Record Group 40, Container 2063C, File 522-2 and Record Group 4, Container 0248, file 4004.

53. Letter from Normand Bernier, recteur général, bibliothèque centrale de prêt de l'estrie, inc. to R. Turpin dated November 21st, 1994.

54. McGill Archives, Record Group 40, Container 21, Box 20, file 1935/R - 1937/Carnegie, T. Lomer's 1936 file, and Record Group 40, Container 22, box 21, 1937/ Chancellor 1937/Z.

55. McLennan, John Stewart, Francis and Isabella, copy of letter dated March 1st, 1928, addressed to Principal Sir Arthur Currie of McGill and found in the files of the School of Architecture.

56. Conversation, R. Turpin with Mr. David Bourke on February 15, 1995.

57. The Montreal Gazette, October 6, 1942.

58. The Montreal Star, July 25, 1944 \& The Montreal Gazette, Sept. 26th, 1944.

59. Typed list dated November 11, 1942, found in McGill Archives, Record Group 40, Container 25, Box 24, File "Letters of G. Lomer (1936-48) and F.C. James (1943) to I.C. McLennan."

60. McGill Archives, Record Group 4, Container No. 2481209A, file 4006.

61. McGill Archives, McLennan Travelling Libraries Microfilm, film MF-1652, reel 2 and Record Group 4, Container No. 248-1209A, file 4006 .

62. Sixty-four of the books Francis donated to McGill are currently listed on MUSE under his name.

63. McGill Archives, Letter to I.C. McLennan from University Librarian dated June 15, 1956, Record Group 40, Container C-1, Box 42. Most of her letters at that time were addressed to Professor Henry Reade Charles (H.R.C.) Avison, but in May 1953, she began to address him as "Dr." 64. McGill University Annual Report, Auditor's Report pp. $232 \& 234$.

65. Frost, Stanley Brice, McGill University for the Advancement of Learning, Vol. II, 1895-1971, p. 73 and Note 29 for that chapter.

66. Letter to R. Turpin from Richard Pennington dated 17 February 1995.

67. Richard Pennington letter to R. Turpin dated February 17 th, 1995.

68. R. Turpin's phone conversation with Miss Allison Cole of October 20th, 1994. The Commedia dell'Arte was "the name usually given to the popular Italian improvised comedy first recorded in 1545, which flourished from the 16th to the early 18th centuries." The actors were trained professionals who collaborated in groups, improvising dialogue and situations around a previously agreed synopsis. Each member of a company "had his or her own character or 'mask'" (The Oxford Companion to the Theatre, ed. Phyllis Hartnell, 4th ed., Oxford: Oxford University Press, 1983).

69. Letter of Professor Hugh McLennan to R. Turpin dated September 12, 1994.

70. R. Turpin's telephone conversation with John Stewart McLennan (né 1915) of Tyringham, Mass. on July 21st, 1995.

71. Westley, Margaret W., Remembrance of Grandeur: The Anglo-Protestant Elite of Montreal, 1900-1950, p. 34.

72. Collard, Edgar Andrew, Call Back Yesterdays, (Don Mills: Longmans Canada Limited, 1965), p. 224.

73. Dau Blue Books for Montreal, Ottawa \& Quebec, published by Dau Publishing Company and various others, in Montreal or New York, between 1897 and 1930; found in McGill Rare Books Department, Fraser-Hickson Library and the Periodicals Section of the Quebec Archives. The Ladies Morning Musical Club, which is still operating, but now does so only in the afternoons, was founded in 1892 by a group of women amateur musicians. (R. Turpin's phonecall with P.R. person at L.M.M.C. on October 12 and 13, 1994). The St. Andrew's Society was founded in 1816, and had its first Ball in 1835. It admitted its first women to full membership in 1902 ; prior to this they could only serve on the women's committees. (R. Turpin's phonecalls in August and September 1994 with two secretaries of the St. Andrew's Society, Margaret Fordham (former secretary) and Norma King (present secretary). 